\title{
LOCATION, WORKING CAPITAL, CORPORATE GOVERNANCE, AND PROFITABILITY: THE CASE OF INDONESIAN MANUFACTURING FIRMS
}

\author{
Irene Rini Demi Pangestuti* \\ Universitas Diponegoro, Indonesia \\ Komang Yuli Pridarsanti \\ Universitas Diponegoro, Indonesia \\ Robiyanto Robiyanto \\ Satya Wacana Christian University, Indonesia
}

\begin{abstract}
This study scrutinizes the effect of location, working capital and corporate governance toward return on assets (ROA) in Indonesian manufacturing firms. 61 manufacturing firms listed on the Indonesia Stock Exchange were taken as samples in this study. The results show that location does not affect manufacturing firms' profitability. Furthermore, this study proves that working capital management, as measured by current ratio (CR) and quick ratio (QR), has a positive and significant influence on return on assets (ROA), but cash ratio (CR) and the cash conversion cycle does not have a significant influence on return on assets (ROA). This study also found that the Good Corporate Governance Index (GCGI) has a positive and significant influence on return on assets (ROA) in Indonesian manufacturing firms.
\end{abstract}

Keywords: Location, Working Capital, Corporate Governance, Profitability, Indonesian Manufacturing Firms.

Received: 15 January 2019

Accepted: 10 May 2021

https://doi.org/10.33736/ijbs.3765.2021

\section{INTRODUCTION}

Increased profits will increase the company's stock price which results in an increase in capital gains for shareholders (Rehman et al., 2015). Therefore, the ability to generate profits/profitability is important for the company. The profitability ratio reflects the company's ability to generate profits by using investments that have been made. One of the profitability ratios that is commonly used as a performance measure is Return on Assets (ROA). The higher the value of ROA, the more effective and efficient a company uses its assets. ROA that continues to grow is considered a positive signal for the company's management and stakeholders regarding the company's degree of sustainability (Riyanto, 2011).

\footnotetext{
- Corresponding author: Faculty of Economics and Business, Universitas Diponegoro, Jl. Erlangga Tengah No. 17, Semarang 50246, Central Java, Indonesia; Tel. +628122895183; E-mail: irenerinidp@live.undip.ac.id.
} 
Ideally, the stakeholders will expect an increase in the company's ability to generate profits from year to year. However, if the opposite happens, then it can be considered a bad sign for the company. Figure 1. shows that in the period of 2014-2017, there was a decrease in the average ROA from year to year for manufacturing companies listed on the Indonesia Stock Exchange (IDX) in 2013-2017. This phenomenon is alarming since the ability of the average manufacturing company to generate a return on investment in assets has decreased continuously. Therefore, improvements are needed. The location, working capital management and Good Corporate Governance (GCG) are examples that can allegedly affect the profitability of a company (Handriani \& Robiyanto, 2018b; Shah et al., 2016).

Figure 1: The average of ROA of Manufacturing Companies Listed on the IDX in 2013-2017

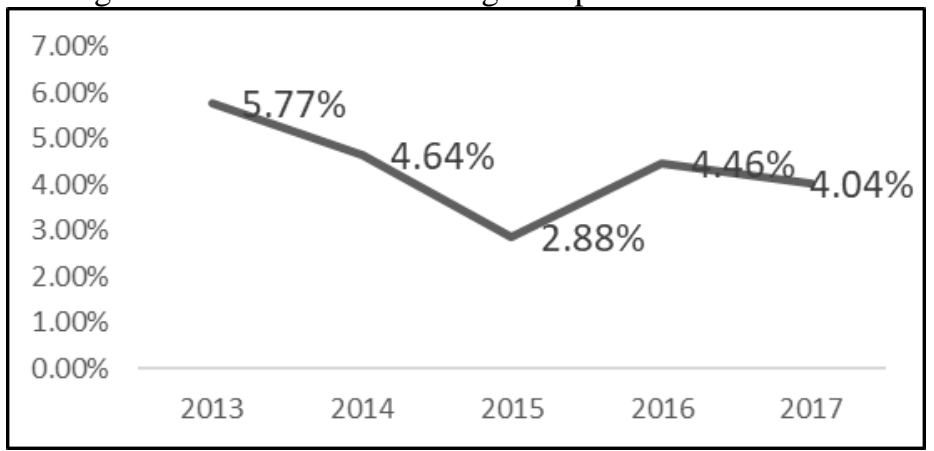

Source: Indonesian Capital Market Directory, processed.

The concept of excellence in multinational companies explains that companies, which are located in more than one country (multinational), have the potential to show better performance than domestic companies. This is because of various advantages, such as production cost efficiency and a broader market share. This statement is supported by the research of Albis and Álvarez (2017); Hintošová and Kubíková (2016); Shah et al. (2016) which shows that location has a positive and significant influence on a company's performance. In contrast, the research results by Barbosa and Louri (2005); Talpová (2016) found that location does not have a significant influence on a company's performance.

In relation to the influence of working capital management on profitability, Ameer (2012), Durrah et al. (2016), and Safdar et al. (2016) conducted studies using cash ratio as a proxy for working capital management on ROA as a proxy for profitability. These studies concluded that companies with high amounts of cash can avoid the risk of financial difficulties and costs incurred to obtain funding sources both from external loans and liquidation of assets owned by the company. This would support an increase in the company's profitability. In contrast, studies by Bagchi and Chakrabarti (2014) found that the cash ratio has a negative and significant influence on ROA.

Another variable that can affect profitability is corporate governance which is often referred to as Good Corporate Governance (GCG). Cheung et al. (2007); Chong et al. (2016); Muharam et al. (2020); Owusu and Weir (2016); Robiyanto et al. (2019) conducted a study whose results supported that there was a positive and significant influence of GCG on ROA. However, in contrast, Shah et al. (2016) shows that their research results supported the results saying that there 
was a negative and significant influence of GCG on ROA. In addition to the two results of the study, Gupta et al. (2009); Leng (2004) also supported the results saying that there was no significant influence of GCG on company profitability.

Some previous studies i.e. Sayidah (2007) and Purnamawati et al. (2017) found that GCG implementation in Indonesia was still below expectations by using 2003 and 2012 data. Fortunately, in recent years, the Financial Service Authority (FSA) in Indonesia has launched some regulations on GCG implementation for public companies in order to increase the quality of the implementation. For example, the FSA regulation on General Meeting of Shareholder, Board of Director and Commissioner, Audit Committee, and the Corporate Secretary (POJK No. 32POJK.04-2014; POJK No. 33-POJK.04-2014; POJK No. 34-POJK.04-2014; POJK No. 35POJK.04-2014); Annual Report (POJK No. 29-POJK.04-2016); Comply or Explain (POJK No. 21-POJK.04-2015). Hopefully, these regulations can improve public companies' willingness to improve their GCG implementation quality. In return, hopefully, these actions can improve its profitability.

Research involving the influence of location as a variable on profitability in Indonesia are still very rare. Further, it can be seen that there is still a need to further study the influence of working capital and GCG management as variables in Indonesia. Therefore, this study examined the influence of location, working capital management measured by the current ratio $(\mathrm{CR})$, quick ratio $(\mathrm{QR})$, cash ratio $(\mathrm{CaR})$ and cash conversion cycle (CCC), as well as the influence of GCG. In addition to the dependent and independent variables, this study also used control variables to obtain a more complete research model. The use of control variables was expected to provide better research results (Bagchi \& Chakrabarti, 2014; Shah et al., 2016). The control variable used in this study was sales growth. In accordance with the concept of corporate growth, one type of company growth was sales growth. Sales growth is a change in sales that the company can achieve in the current year compared to the previous year (Shah et al., 2016). The higher the sales growth, the more sales. As a result, profits will be even greater. The use of sales growth as a control variable was based on the research conducted by Bagchi and Chakrabarti (2014); Hoang (2015); Shah et al. (2016); Tahir and Anuar (2015). It was also based on a consideration of the significance of the influence of sales growth on the profitability of the company. Therefore, in order to gain a better understanding of the influence of these variables as the focus of the study, the influence of this variable also needed to be controlled.

\section{LITERATURE REVIEW}

\subsection{Company Profitability}

One way to measure profitability is through the company's ability to optimize the use of its assets productively, namely by using Return on Assets (ROA). ROA is a ratio measuring a company's ability to generate net income by using the asset investments made. (Aqil et al., 2019; Ernayani et al., 2017; Ruangchoengchum, 2017). To increase ROA, company management can take policies related to investment in assets and increase the efficiency of production, sales and administration (Handriani \& Robiyanto, 2018a). 


\subsection{Company Location}

Companies that are located and operating in more than one country are referred to as multinational companies (Brigham \& Houston, 2012). Meanwhile, companies located in one country and owned, run and controlled by local residents are referred to as domestic companies (Shah et al., 2016). Shah et al. (2016) stated that multinational companies operating in more than one country have several advantages. Thus, multinational companies are expected to have better profitability than domestic companies. Support for better performance of multinational companies from domestic companies also came from other studies conducted by Albis and Álvarez (2017). Based on the explanation above, the hypothesis that can be formulated is as follows:

\section{H1: Location has a positive influence on profitability}

\subsection{Working Capital Management}

The working capital policy is a policy taken by the company management related to the target of each type of current asset and how the current assets will be funded. The management of the company's net working capital (i.e. liquidity) involves decisions regarding investment in current assets and interrelated short-term liabilities (Keown et al., 2008). The working capital management can be proxied by using the current ratio (CR), quick ratio $(\mathrm{QR})$, cash ratio $(\mathrm{CaR})$ and cash conversion cycle (CCC). Three liquidity ratios were used in this study, because the liquidity ratios showed the more liquid asset to fulfill short-term liabilities, i.e. CaR employs more liquid assets than the current ratio.

Based on this, the following are the hypotheses that can be formulated:

H2: Current ratio has a positive influence on profitability

H3: Quick ratio has a positive influence on profitability

H4: Cash ratio has a positive influence on profitability

H5: Cash conversion cycle has a positive influence on profitability

\subsection{Good Corporate Governance (GCG)}

The agency theory by Jensen and Meckling (1976) explains that there are differences in interests between the company managers as agents and the owners of companies as the principal. The main problem in agency conflict is a lack of supervision and accountability (Handriani \& Robiyanto, 2019; Mai, 2017; Orazalin et al., 2016; Owusu \& Weir, 2016).

The positive influence of GCG on company performance is supported by research by Cheung et al. (2007) which examined 168 large companies listed on the Hong Kong Stock Exchange in 2002. Owusu and Weir (2016) examined companies listed on the Ghana stock exchange in 2004-2009 to determine the company's compliance with Ghana's GCG Guidelines and their impact on company performance (ROA, ROE, Tobin's Q). The results obtained support the idea that the higher the GCGI, the higher the performance of the company. Furthermore, a study by Chong et al. (2016) in 
REITs companies in Singapore in 2008-2012 also underlined that there was a positive impact of GCG implementation on the company profitability (ROA). Therefore, based on the above explanation, the hypothesis that can be proposed is as follows:

\section{H6: GCG has a positive influence on profitability}

\subsection{Sales Growth as A Control Variable}

Positive sales growth means that there is an increase in the company's ability to make sales from year to year. This increase in sales means an increase in the company's revenue. By using the assumption of the economies of scale, when the number of goods produced and sold increases, the average cost per product unit will decrease. This will affect the greater profit that can be achieved by the company, resulting in an increase of ROA. The positive influence of sales growth on ROA had been supported by the research results by Hoang (2015) and Shah et al. (2016). The use of sales growth as a control variable created a higher $\mathrm{R}$-square value so that the research model gets better.

\section{METHODOLOGY}

\subsection{Data}

The data used in this study was secondary data from the annual report in 2013-2017. The data was obtained through the Indonesia Stock Exchange (IDX) website. The related data was obtained through the Indonesian Capital Market Directory.

\subsection{Population and Sample}

The population of this study was all of the manufacturing companies listed on the Stock Exchange in 2013-2017. As of 2017, there were 144 companies in the manufacturing sector listed on the IDX and this became the population of this study. The sample of the study was determined by a purposive sampling method. The criteria included:

1) Manufacturing companies listed on the Stock Exchange consistently in the period of 20132017 and had never been delisted from the stock exchange.

2) The financial report period ended on December $31^{\text {st }}$ because the full financial year in Indonesia is ended on December $31^{\text {st }}$. This action based on the Financial Service Authority's regulation concerning the financial report.

3) Generated positive ROA. This criterion included avoiding severe skewness in data as suggested by Thornblad et al. (2018).

4) Having complete data on other variables used in this study, such as location, current ratio, quick ratio, cash ratio, cash conversion cycle, total sales data and annual report that can be used to determine the value of the Good Corporate Governance Index (GCGI) for the period of 2013-2017.

The number of samples used in this study can be seen in Table 1 . 
Table 1: Sample Determination

\begin{tabular}{lc}
\hline \hline \multicolumn{1}{c}{ Criteria } & Number of Companies \\
\hline $\begin{array}{l}\text { Manufacturing companies listed on the Indonesia Stock Exchange in } \\
\text { the period of 2013-2017 }\end{array}$ & 144 \\
Companies whose financial statements do not end in December 31 st* & $(2)$ \\
Companies that generate negative ROA & $(55)$ \\
Companies whose variable data are incomplete & $(26)$ \\
Companies which become the research sample & 61 \\
\hline \hline
\end{tabular}

Source: Indonesian Capital Market Directory, processed.

Notes: The full financial year in Indonesia ends on December $31^{\text {st }}$. This action based on the Financial Service Authority's regulation concerning the financial report.

The number of research samples was 61 companies with the observation years starting from 2013 to 2017 (5 years), resulting in 305 observations.

\subsection{Research Variables and Operational Definitions}

In short, the variables used in this study can be seen in Table 2 .

Table 2: Operational Definition

\begin{tabular}{|c|c|c|c|}
\hline Variable & Definition & Scale & Formula \\
\hline \multirow{2}{*}{$\begin{array}{l}\text { Profitability } \\
\text { (ROA) }\end{array}$} & \multirow{2}{*}{$\begin{array}{l}\text { A ratio of earnings } \\
\text { after taxes (EAT) on } \\
\text { total assets }\end{array}$} & \multirow[t]{2}{*}{ Ratio } & Earning After Taxes \\
\hline & & & $\begin{array}{l}\text { Total Assets } \\
\text { (Brigham \& Houston, 2012; Shah et al., 2016), } \\
\text { taken from the Indonesian Capital Market } \\
\text { Directory. }\end{array}$ \\
\hline Location (LOC) & $\begin{array}{l}\text { Companies } \\
\text { operating in more } \\
\text { than one country } \\
\text { (multinational) or } \\
\text { operating in one } \\
\text { country (domestic) }\end{array}$ & Dummy & $\begin{aligned} & 1=\text { Multinational Company } \\
& 0=\text { Domestic Company } \\
& \text { (Shah et al., 2016) }\end{aligned}$ \\
\hline \multirow{2}{*}{$\begin{array}{l}\text { Current } \\
(\mathrm{CR})\end{array}$} & \multirow{2}{*}{$\begin{array}{l}\text { A ratio of the total } \\
\text { current assets to } \\
\text { total short-term } \\
\text { liabilities }\end{array}$} & \multirow[t]{2}{*}{ Ratio } & Total Current Assets \\
\hline & & & $\begin{array}{l}\text { Total Short - term Liabilities } \\
\text { (Brigham \& Houston, 2012; Munawir, 2007; } \\
\text { Shah et al., 2016), taken from the Indonesian } \\
\text { Capital Market Directory. }\end{array}$ \\
\hline \multirow[t]{2}{*}{ Quick Ratio (QR) } & \multirow{2}{*}{$\begin{array}{l}\text { A ratio of total } \\
\text { current assets minus } \\
\text { inventory to total } \\
\text { short-term liabilities }\end{array}$} & \multirow[t]{2}{*}{ Ratio } & Total Current Assets - Inventor \\
\hline & & & $\begin{array}{l}\text { Total Short - term Liabilities } \\
\text { (Durrah et al., 2016; Rehman et al., 2015; } \\
\text { Shah et al., 2016), taken from the Indonesian } \\
\text { Capital Market Directory. }\end{array}$ \\
\hline \multirow[t]{2}{*}{ Cash Ratio (CaR) } & \multirow{2}{*}{$\begin{array}{l}\text { A ratio of total cash } \\
\text { and cash equivalents } \\
\text { to short-term } \\
\text { liabilities }\end{array}$} & \multirow[t]{2}{*}{ Ratio } & Cash Eq \\
\hline & & & $\begin{array}{l}\text { Total Short - term Liabilities } \\
\text { (Durrah et al., 2016; Rehman et al., 2015; } \\
\text { Shah et al., 2016), estimated by authors. }\end{array}$ \\
\hline $\begin{array}{l}\text { Cash Conversion } \\
\text { Cycle (CCC) }\end{array}$ & $\begin{array}{l}\text { Sum of inventory } \\
\text { conversion period } \\
\text { plus average }\end{array}$ & Ratio & $\begin{array}{l}\mathrm{CCC}=\text { inventory conversion period }+ \\
\text { average collection period }- \text { payment deferral } \\
\text { period }\end{array}$ \\
\hline
\end{tabular}




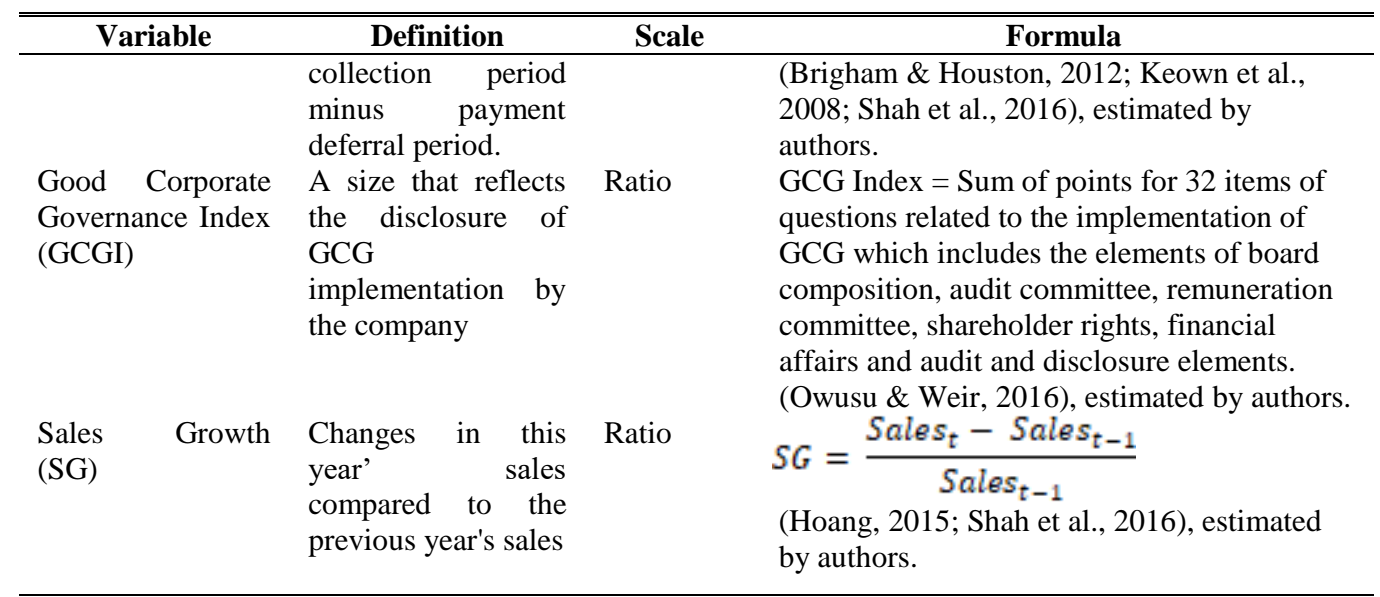

Source: Authors' compilations.

\subsection{Data Analysis Technique}

To understand the influence of location (Loc.), working capital management (CR, QR, CaR, CCC) and the application of GCG (GCGI) on the company profitability (ROA), this study used multiple regression analysis techniques with the following models:

Model 1 (without any control variable):

$\mathrm{ROA}=\alpha+\beta 1 \mathrm{Loc}+\beta 2 \mathrm{CR}+\beta 3 \mathrm{QR}+\beta 4 \mathrm{CaR}-\beta 5 \mathrm{CCC}+\beta 6 \mathrm{GCGI}+\varepsilon$

Model 2 (with sales growth as the control variable):

$\mathrm{ROA}=\alpha+\beta 1 \mathrm{Loc}+\beta 2 \mathrm{CR}+\beta 3 \mathrm{QR}+\beta 4 \mathrm{CaR}-\beta 5 \mathrm{CCC}+\beta 6 \mathrm{GCGI}+\beta 7 \mathrm{SG}+\varepsilon$

Where:

$\begin{array}{ll}\text { ROA } & \text { : Return on Assets } \\ \text { Loc } & : \text { Location } \\ \text { CR } & : \text { Current Ratio } \\ \text { QR } & : \text { Quick Ratio } \\ \text { CaR } & : \text { Cash Ratio } \\ \text { CCC } & : \text { Cash Conversion Cycle } \\ \text { GCGI } & : \text { Good Corporate Governance Index } \\ \text { SG } & : \text { Sales Growth } \\ \alpha & : \text { Constanta } \\ \beta 1-\beta 7 & : \text { Regression Coefficient } \\ \varepsilon & : \text { Residual Variable }\end{array}$




\section{RESULTS AND DISCUSSION}

\subsection{Descriptive Statistics}

Table 3 presents the descriptive statistics of the research variables which include return on assets (ROA), location (Loc.), current ratio $(\mathrm{CR})$, quick ratio $(\mathrm{QR})$, cash ratio $(\mathrm{CaR})$, cash conversion cycle (CCC) and good corporate governance index (GCGI).

Table 3: Research Variable Descriptive Statistics

\begin{tabular}{|c|c|c|c|c|c|c|c|}
\hline No. & Variable & $\begin{array}{l}\text { Amount } \\
\text { of Data }\end{array}$ & $\begin{array}{l}\text { Range } \\
\text { of } \\
\text { Value }\end{array}$ & $\begin{array}{l}\text { Minimu } \\
\text { m Value }\end{array}$ & $\begin{array}{l}\text { Maximum } \\
\text { Value }\end{array}$ & Average & $\begin{array}{l}\text { Std. } \\
\text { Deviation }\end{array}$ \\
\hline \multirow[t]{6}{*}{1.} & ROA (\%) 2013-2017 & 305 & 71.47 & 0.04 & 71.51 & 8.56 & 9.56 \\
\hline & ROA (\%) 2013 & 61 & 71.43 & 0.08 & 71.51 & 10.17 & 12.92 \\
\hline & ROA (\%) 2014 & 61 & 40.14 & 0.04 & 40.18 & 8.51 & 8.71 \\
\hline & ROA (\%) 2015 & 61 & 37.16 & 0.04 & 37.20 & 7.61 & 7.72 \\
\hline & ROA (\%) 2016 & 61 & 43.10 & 0.07 & 43.17 & 9.02 & 8.68 \\
\hline & ROA (\%) 2017 & 61 & 52.61 & 0.06 & 52.67 & 7.49 & 8.99 \\
\hline \multirow[t]{6}{*}{2.} & $\begin{array}{l}\text { Loc.(dummy) 2013- } \\
2017\end{array}$ & 305 & 1 & 0 & 1 & 0.43 & 0.496 \\
\hline & Loc.(dummy) 2013 & 61 & 1 & 0 & 1 & 0.43 & 0.498 \\
\hline & Loc.(dummy) 2014 & 61 & 1 & 0 & 1 & 0.43 & 0.499 \\
\hline & Loc.(dummy) 2015 & 61 & 1 & 0 & 1 & 0.43 & 0.498 \\
\hline & Loc.(dummy) 2016 & 61 & 1 & 0 & 1 & 0.43 & 0.498 \\
\hline & Loc.(dummy) 2017 & 61 & 1 & 0 & 1 & 0.44 & 0.500 \\
\hline \multirow[t]{6}{*}{3.} & CR (\%) 2013-2017 & 305 & 632.58 & 40.31 & 672.89 & 217.83 & 124.36 \\
\hline & CR (\%) 2013 & 61 & 632.58 & 40.31 & 672.89 & 209.78 & 116.98 \\
\hline & CR (\%) 2014 & 61 & 523.41 & 45.03 & 568.44 & 209.44 & 116.98 \\
\hline & CR (\%) 2015 & 61 & 598.32 & 58.42 & 656.74 & 216.59 & 129.98 \\
\hline & CR (\%) 2016 & 61 & 521.44 & 60.56 & 582.00 & 220.79 & 124.90 \\
\hline & CR (\%) 2017 & 61 & 586.85 & 63.37 & 650.22 & 232.53 & 134.61 \\
\hline \multirow[t]{6}{*}{4.} & QR (\%) 2013-2017 & 305 & 454.00 & 8.00 & 462.00 & 112.41 & 83.12 \\
\hline & QR (\%) 2013 & 61 & 434.97 & 11.03 & 446.00 & 110.30 & 82.54 \\
\hline & QR (\%) 2014 & 61 & 359.00 & 8.00 & 367.00 & 109.81 & 85.73 \\
\hline & QR (\%) 2015 & 61 & 291.00 & 13.00 & 304.00 & 108.64 & 81.09 \\
\hline & QR (\%) 2016 & 61 & 371.00 & 15.00 & 386.00 & 113.71 & 82.93 \\
\hline & QR (\%) 2017 & 61 & 444.91 & 17.09 & 462.00 & 119.59 & 85.51 \\
\hline \multirow[t]{6}{*}{5.} & $\mathrm{CaR}(\%)$ 2013-2017 & 305 & 350.52 & 0.48 & 351.00 & 45.88 & 57.59 \\
\hline & $\mathrm{CaR}(\%) 2013$ & 61 & 350.48 & 0.52 & 351.00 & 45.95 & 60.41 \\
\hline & $\mathrm{CaR}(\%) 2014$ & 61 & 277.60 & 0.48 & 278.08 & 42.51 & 59.99 \\
\hline & $\mathrm{CaR}(\%) 2015$ & 61 & 195.01 & 0.99 & 196.00 & 44.61 & 52.47 \\
\hline & $\mathrm{CaR}(\%) 2016$ & 61 & 255.67 & 0.66 & 256.33 & 48.01 & 56.70 \\
\hline & $\mathrm{CaR}(\%) 2017$ & 61 & 257.07 & 1.32 & 258.39 & 48.30 & 59.68 \\
\hline \multirow[t]{5}{*}{6.} & $\begin{array}{l}\text { CCC (days) 2013- } \\
2017\end{array}$ & 305 & 408.56 & -29.28 & 379.28 & 116.64 & 76.49 \\
\hline & CCC (days) 2013 & 61 & 338.12 & -29.28 & 308.84 & 115.30 & 76.45 \\
\hline & CCC (days) 2014 & 61 & 352.82 & -25.83 & 326.99 & 114.93 & 76.91 \\
\hline & CCC (days) 2015 & 61 & 326.88 & -19.62 & 307.26 & 112.26 & 70.93 \\
\hline & CCC (days) 2016 & 61 & 341.58 & -10.78 & 330.80 & 118.75 & 81.51 \\
\hline
\end{tabular}




\begin{tabular}{llllllll} 
& CCC (days) 2017 & 61 & 395.83 & -16.55 & 379.28 & 121.95 & 78.41 \\
\hline 7. & GCGI (index) 2013- & 305 & 14 & 16 & 30 & 22.98 & 3.00 \\
2017 & & & & & & \\
GCGI (index) 2013 & 61 & 10 & 17 & 27 & 21.30 & 2.29 \\
GCGI (index) 2014 & 61 & 11 & 17 & 28 & 21.79 & 2.39 \\
& GCGI (index) 2015 & 61 & 13 & 16 & 29 & 23.26 & 2.92 \\
& GCGI (index) 2016 & 61 & 12.00 & 17.00 & 29.00 & 23.92 & 2.93 \\
& GCGI (index) 2017 & 61 & 13.00 & 17.00 & 30.00 & 24.66 & 3.05 \\
\hline 8. & SG (\%) 2013-2017 & 305 & 177.31 & -50.00 & 127.31 & 10.40 & 16.67 \\
& SG (\%) 2013 & 61 & 145.39 & -18.08 & 127.31 & 22.84 & 24.34 \\
& SG (\%) 2014 & 61 & 73.91 & -27.70 & 46.21 & 10.29 & 13.08 \\
& SG (\%) 2015 & 61 & 86.22 & -37.88 & 48.34 & 4.88 & 12.09 \\
& SG (\%) 2016 & 61 & 86.48 & -50.00 & 36.48 & 7.11 & 13.58 \\
SG (\%) 2017 & 61 & 54.70 & -23.68 & 31.02 & 6.87 & 10.07 \\
\hline \hline
\end{tabular}

Source: Indonesian Capital Market Directory, processed.

From 305 observations, it can be seen that the smallest positive ROA value is $0.04 \%$ and the largest value is $71.51 \%$ with a value range of 71.47 . The smallest ROA is shown by PT Star Petrochem Tbk in 2014, while the largest value of ROA is shown by PT Unilever Indonesia Tbk in 2013. Overall, for 2013-2017, ROA has an average value of $8.56 \%$ with a standard deviation or the average distance of deviations from data points from an average value of $9.56 \%$.

In relation to location as a variable which is a dummy variable, Table 3 . shows that the average value of this variable is 0.43 . It means that $43 \%$ of all research data samples are multinational manufacturing companies (dummy 1). The number of sample data of this multinational manufacturing company is 130 (43\% of 305 samples) and the remaining 175 samples are domestic manufacturing companies. Based on this distribution, it shows that multinational and domestic manufacturing companies have almost balanced samples.

The CR variable has a minimum value of $40.31 \%$ and a maximum value of $672.89 \%$ with a value range of $632.58 \%$. The lowest CR of $40.31 \%$ is shown by PT Nusantara Inti Corpora Tbk in 2013, while the highest CR value of $672.89 \%$ is shown by PT Lion Metal Works Tbk in 2013. Based on the sample, CR has an average value of $217.83 \%$ with a standard deviation of $124.36 \%$.

The next description is about the QR variable, where it has a minimum value of $8.00 \%$ and a maximum value of $462.00 \%$ with a value range of $454.00 \%$. The minimum QR value $(8.00 \%)$ is shown by PT HM Sampoerna Tbk in 2014, while the maximum QR value of $462.00 \%$ is shown by PT Champion Pacific Indonesia Tbk in 2017. Overall, QR has an average value of $112.41 \%$ with a standard deviation of $83.12 \%$.

For the $\mathrm{CaR}$ variable, the minimum $\mathrm{CaR}$ value is $0.48 \%$ and the maximum value is $351.00 \%$ with a value range of $350.52 \%$. The lowest CaR is shown by PT HM Sampoerna Tbk in 2014, while the highest CaR value is shown by PT Lion Metal Works Tbk in 2013. The average value of the CaR is $45.88 \%$ with a standard deviation of $57.59 \%$.

The minimum CCC is -29.28 days and the maximum CCC is 379.80 days with a value range of 408.56. The shortest CCC is shown by PT Indo-Rama Synthetics Tbk in 2013, while the longest 
CCC is shown by PT Nusantara Inti Corpora Tbk. The average CCC value was 6.64 days with a standard deviation of 76.49 days.

The minimum average value of the Good Corporate Governance Index (GCGI) is 16, while the maximum value is 30. The lowest GCGI value is shown by PT Tempo Scan Pacific Tbk in 2015, while the highest is shown by PT Unilever Indonesia Tbk in 2017, PT Astra Otoparts Tbk in 2017, PT Japfa Comfeed Indonesia Tbk 2017 and PT Kalbe Farma Tbk in 2017. The average GCGI was 22.98 with a standard deviation of 3.00 .

The minimum SG is equal to $-50.00 \%$ shown by PT Star Petrochem Tbk in 2016, while the maximum is $127.31 \%$ shown by PT Multi Bintang Indonesia Tbk in 2013. This range of values or the difference between the highest and lowest value of SG is equal to $177.31 \%$. The average sales growth was $10.41 \%$ with a standard deviation of $16.67 \%$.

\subsection{Normality Test}

The results of the Kurtosis Skewness Test of Model 1 and Model 2 (can be seen in Table 7. and Table 8.) show that the probability of the $S-K$ test is much smaller than $\alpha(0.000<0.050)$. Thus, it can be concluded that there is a deviation from the assumption of the residual normality. Therefore, corrective action is needed to solve this problem.

The variable data transformation carried out is the transformation of ROA into square root while other variables are allowed to remain. Furthermore, the detection of data outliers also be done to obtain residual normality. After the outlier was detected and excluded, the original data of 305 observations became 225 observations. The detection results of residual normality deviations after the data was transformed can be seen in Table 7 and Table 8.

The results of the Kurtosis Skewness test show that the probability of the S-K test in Model 1 $(0.5962>0.0500)$ and Model $2(0.4210>0.0500)$ is far greater than the significance value $(\alpha=$ $5 \%$ ). Thus, it can be concluded that the assumption of residual normality has been fulfilled, and in other words, the residual variable has been normally distributed.

\subsection{Multicollinearity Test}

The following are the results of the multicollinearity tests conducted on Model 1 (without control variables) and Model 2 (with control variables).

Table 4: Result of Multicollinearity Test of Model 1

\begin{tabular}{lcc}
\hline \hline \multicolumn{1}{c}{ Variable } & VIF & 1/VIF \\
\hline Loc & 1.15 & 0.869555 \\
CR & 3.44 & 0.290848 \\
QR & 4.45 & 0.358241 \\
CaR & 2.79 & 0.358241 \\
CCC & 1.47 & 0.680347 \\
GCGI & 1.07 & 0.937522 \\
\hline \hline
\end{tabular}

Source: Indonesian Capital Market Directory, processed. 
Based on the VIF value generated from multicollinearity tests on Model 1 and Model 2, it can be seen that the VIF value for all independent variables is smaller than 10 .

Table 5: Result of Multicollinearity Test of Model 2

\begin{tabular}{ccc}
\hline \hline Variable & VIF & 1/VIF \\
\hline Loc & 1.15 & 0.869553 \\
CR & 3.44 & 0.290845 \\
QR & 4.45 & 0.224624 \\
CaR & 2.80 & 0.356787 \\
CCC & 1.47 & 0.678824 \\
GCGI & 1.07 & 0.934137 \\
SG & 1.04 & 0.965137 \\
\hline \hline
\end{tabular}

Source: Indonesian Capital Market Directory, processed.

\subsection{Heteroscedasticity Test}

To examine whether heteroscedasticity problems occur in Model 1 (without control variables) and Model 2 (with control variables), the Breusch-Pagan/Cook-Weisberg Test was used. The results of heteroscedasticity testing can be seen in Table 7 and Table 8 It can be seen that the Chi ${ }^{2}$ values of the Breusch-Pagan/ Cook-Weisberg test results in both Model 1 (without control variables) and Model 2 (with control variables) have a much greater probability of significance $(\alpha=5 \%)$. Thus, it can be concluded that the assumption of that heteroscedasticity does not occur has been fulfilled.

\subsection{Multiple Linear Regression Analysis}

This study used a multiple linear regression analysis which referred to the research objectives, namely to determine the influence of independent variables such as location (Loc), current ratio $(\mathrm{CR})$, quick ratio $(\mathrm{QR})$, cash ratio $(\mathrm{CaR})$, cash conversion cycle $(\mathrm{CCC})$ and good corporate governance index (GCGI) and for return on assets (ROA) as the dependent variable. Furthermore, the results of this multiple regression analysis will be described in the research data, which includes the goodness of fit model with a coefficient of determination $\left(\mathrm{R}^{2}\right), \mathrm{F}$ test and test of significance of individual parameters (t-test). The model used in this study is a common effect model because the Chow Test for Model 1 produces Chi-Square statistics equal to 1.224 which is not significant at $5 \%$ level, and the Chow Test for Model 2 produces Chi-Square statistics equal to 6.369 which is not significant at $5 \%$ level.

\subsubsection{The Unobserved Effect Test}

A common problem with pool regression is that the estimated results can be biased in the presence of unobserved effect. To test the existence of the unobserved effect, this study used the redundant fixed-effect test. The null hypothesis of the redundant fixed-effect test is that there is no unobserved heterogeneity (Kinkyo et al., 2016). If the p-values of the Chi-Square statistics and F statistics are higher than 5\%, it concludes that no unobserved effect exists. Table 6 shows no unobserved effect existed. 
Table 6: The Result of Redundant Fixed-Effect Tests

\begin{tabular}{llrc}
\hline \multicolumn{1}{c}{ Effects Test } & Statistic & \multicolumn{1}{c}{ d.f. } & Prob. \\
\hline Cross-section F & 1.222481 & $-60,234$ & 0.1441 \\
Cross-section Chi-square & 72.10841 & 60 & 0.1359 \\
Period F & 1.854022 & $-4,234$ & 0.1193 \\
Period Chi-square & 7.459434 & 4 & 0.1135 \\
Cross-Section/Period F & 1.057948 & $-64,234$ & 0.3741 \\
Cross-Section/Period Chi-square & 73.66848 & 64 & 0.1912 \\
\hline \hline
\end{tabular}

Source: Indonesian Capital Market Directory, processed.

\subsubsection{The Goodness of Fit Analysis}

The results of the testing on Model 1 and Model 2 of this study provide the $\mathrm{R}^{2}$ values which can be seen in Table 7. and Table 8. The goodness of Model 1 (without control variables) gives the results of an adjusted $\mathrm{R}^{2}$ of 0.3605 (36.05\%). This can be interpreted that the variability of the dependent variable ROA could be explained by independent variables such as location, $\mathrm{CR}, \mathrm{QR}$, CaR, CCC and GCGI of $36.05 \%$, while the remaining $63.95 \%$ was explained by other variables not included in the research model. Furthermore, the testing on Model 2 (with sales growth control variables) produced an adjusted $\mathrm{R}^{2}$ value of $0.3848(38.48 \%)$. It explained that the variation of the dependent variable (ROA) could be explained by the independent variables of location, $\mathrm{CR}, \mathrm{QR}$, $\mathrm{CaR}, \mathrm{CCC}$ and GCGI. It also explained that the control variable (SG) was $38.48 \%$, while the remaining $61.52 \%$ was explained by other variables outside the model.

Looking at the value of the coefficient of determination produced by Model $1(36.05 \%)$ and Model $2(38.48 \%)$, it can be said that the regression model used in this study was quite good. The use of $\mathrm{SG}$ as the control variable resulted in an increase in adjusted $\mathrm{R}^{2}$ of $2.43 \%$, from $36.05 \%$ to $38.48 \%$. Therefore, it can be concluded that the use of sales growth as a control variable had produced a better research model.

\subsubsection{Individual Parameter Significance Test}

The results of the t-test performed on Model 1 (without control variables) and Model 2 (with control variables) used in this study can be seen in Table 7 and Table 8 .

Based on the results of the $t$ test, the regression equation for Model 1 can be written as follows:

$\begin{aligned} \mathrm{SRROA}= & -0.1642729+0.0478366 \mathrm{Loc}+0.0034808 \mathrm{CR}+0.0072084 \mathrm{QR}-0.0000717 \mathrm{CaR}- \\ & 0.000576 \mathrm{CCC}+0.0522176 \mathrm{GCGI}+\varepsilon\end{aligned}$

Based on the six independent variables used in Model 1 of this study (see Table 7.), the independent variable that has the highest standardized coefficient (Beta) with a value of 0.3593313 is the QR (Quick Ratio). Therefore, the QR variable is considered as the variable that has the highest influence on the dependent variable (ROA) compared to other independent variables. The results of the significance test of individual parameters for Model 2 can be seen in Table 8. 
Table 7: Result of Individual Parameter Significance Test (t-Test) of Model 1

\begin{tabular}{|c|c|c|c|c|c|}
\hline Predictor & Coef. & Robust Error Std. & Beta & $\mathbf{t}$ & $\mathbf{P}>|\mathbf{t}|$ \\
\hline Loc & 0.0478366 & 0.1229263 & 0.020722 & 0.39 & 0.698 \\
\hline $\mathrm{CR}$ & 0.0034808 & 0.0016198 & 0.2617574 & 2.15 & 0.033 \\
\hline QR & 0.0072084 & 0.0027084 & 0.3593313 & 2.66 & 0.008 \\
\hline $\mathrm{CaR}$ & -0.0000717 & 0.0025721 & -0.0023225 & -0.03 & 0.978 \\
\hline $\mathrm{CCC}$ & -0.000576 & 0.001206 & -0.0320264 & -0.48 & 0.633 \\
\hline GCGI & 0.0522176 & 0.0196273 & 0.1357479 & 2.66 & 0.008 \\
\hline $\mathrm{C}$ & -0.1642729 & 0.4753155 & & -0.35 & 0.730 \\
\hline \multicolumn{3}{|c|}{ Normality Test (Before Transformation) } & S-K Test Value: - & \multicolumn{2}{|c|}{ Prob.: 0.0000} \\
\hline \multicolumn{3}{|c|}{ Normality Test (After Transformation) } & S-K Test Value: 1.03 & \multicolumn{2}{|c|}{ Prob.: 0.5962} \\
\hline \multicolumn{2}{|c|}{ Heteroscedasticity Test } & \multicolumn{2}{|c|}{ Breusch-Pagan/ Cook-Weisberg $\left(\mathrm{Chi}^{2}\right): 0.98$} & \multicolumn{2}{|c|}{ Prob.: 0.3218} \\
\hline \multicolumn{4}{|c|}{ F-Value: 22.040} & \multicolumn{2}{|c|}{ Prob.: 0.0000} \\
\hline \multicolumn{2}{|l|}{$\mathrm{R}^{2}: 0.3776$} & ${ }^{2}: 0.3605$ & & & \\
\hline
\end{tabular}

Source: Indonesian Capital Market Directory, processed.

Table 8: Result of Individual Parameter Significance Test (t-Test) of Model 2

\begin{tabular}{|c|c|c|c|c|c|}
\hline Predictor & Coef. & Robust Error Std. & Beta & $\mathrm{t}$ & $\mathbf{P}>|\mathbf{t}|$ \\
\hline Loc & 0.0472205 & 0.1194097 & 0.0204551 & 0.40 & 0.693 \\
\hline $\mathrm{CR}$ & 0.0034664 & 0.0016451 & 0.2606707 & 2.11 & 0.036 \\
\hline QR & 0.0069848 & 0.0027029 & 0.3481837 & 2.58 & 0.010 \\
\hline $\mathrm{CaR}$ & -0.0006072 & 0.0024345 & -0.019662 & -0.25 & 0.803 \\
\hline $\mathrm{CCC}$ & -0.0004082 & 0.0011866 & -0.0226926 & -0.34 & 0.731 \\
\hline GCGI & 0.0561044 & 0.0191726 & 0.1458524 & 2.93 & 0.004 \\
\hline SG & 0.0175098 & 0.005562 & 0.1654507 & 3.15 & 0.002 \\
\hline $\mathrm{C}$ & -0.4028992 & 0.4729787 & & -0.85 & 0.395 \\
\hline \multicolumn{3}{|c|}{ Normality Test (Before Transformation) } & S-K Test Value: - & \multicolumn{2}{|c|}{ Prob.: 0.0000} \\
\hline \multicolumn{3}{|c|}{ Normality Test (After Transformation) } & S-K Test Value: 1.73 & \multicolumn{2}{|c|}{ Prob.: 0.4210} \\
\hline \multicolumn{2}{|c|}{ Heteroscedasticity Test } & \multicolumn{2}{|c|}{ Breusch-Pagan/ Cook-Weisberg $\left(\mathrm{Chi}^{2}\right): 1.67$} & \multicolumn{2}{|c|}{ Prob.: 0.1957} \\
\hline \multicolumn{3}{|c|}{ F-Value: 21.020} & & \multicolumn{2}{|c|}{ Prob.: 0.0000} \\
\hline \multicolumn{2}{|l|}{$\mathrm{R}^{2}: 0.4040$} & \multicolumn{2}{|l|}{ Adjusted $\mathrm{R}^{2}: 0.3848$} & & \\
\hline
\end{tabular}

Source: Indonesian Capital Market Directory, processed.

From the results of the t-test by adding the Sales Growth (SG) control variable to the regression model, the regression equation for Model 2 is:

$\mathrm{SRROA}=$
$=-0.4028992+0.0472205 \mathrm{Loc}+0.0034664 \mathrm{CR}+0.0069848 \mathrm{QR}-0.0006072 \mathrm{CaR}-$
$0.0004082 \mathrm{CCC}+0.0561044 \mathrm{GCGI}+0.0175098 \mathrm{SG}+\varepsilon$

According to the six independent variables above, the independent variable that has the highest standardized coefficient (Beta) of 0.3481837 is the QR (Quick Ratio). Thus, it can be said that the most influential independent variable on ROA in this study was the $\mathrm{QR}$ variable. 


\subsection{Hypothesis Testing}

\subsubsection{The Influence of Location on Return on Assets (Hypothesis 1)}

The hypothesis testing results regarding the influence of location on return on assets (ROA) shows that location does not have a significant influence on ROA (H1 is rejected). It means that the position of the company as a multinational or domestic company had no influence on the profitability of the companies which used ROA as a measure.

The results of this study are in line with the results of Barbosa and Louri (2005) on a sample of manufacturing companies in Portugal in 1992 and manufacturing companies in Greece in 1997 and Talpová (2016) on 155 multinational companies and 118 domestic companies in the Czech Republic in 2009. This research supported that there was no significant difference between the performance of multinational and domestic companies. The strategies applied by multinational and domestic companies to operate and adjust to their environment would equally affect their performance. Thus, the company's location has no significant influence on company profitability as a measure of performance.

\subsubsection{The Influence of Current Ratio on Return on Assets (Hypothesis 2)}

The second hypothesis testing regarding the positive influence of the current ratio $(\mathrm{CR})$ on return on assets (ROA) supports that CR has a positive and significant influence on ROA (H2 is accepted). It can be interpreted that the higher the $\mathrm{CR}$, the higher the ROA. The positive influence of $\mathrm{CR}$ on ROA is in line with the cost trade-off theory (Tahir \& Anuar, 2016) and the concept of qualitative working capital (Munawir, 2007). The cost trade-off theory states that with large amounts of working capital, companies will avoid unnecessary costs due to lack of working capital when it is needed. A high CR can also mean that the company has sufficient inventory. Companies with adequate inventories usually buy large amounts of inventory so they can get discounted prices from the suppliers. This discount is a cost reduction that has a positive impact on the profitability of the company.

The second hypothesis testing results are in line with the research conducted by Durrah et al. (2016); Hoang (2015); Rehman et al. (2015); Safdar et al. (2016); Shah et al. (2016); Tahir and Anuar (2015) which agreed that the higher the CR value, the higher the ability of the company to produce a return on its investment.

\subsubsection{The Influence of Quick Ratio on Return on Assets (Hypothesis 3)}

The results of statistical tests on the third hypothesis formulated in this study support that quick ratio (QR) has a positive influence and is also significant on return on assets (H3 is accepted). Support of the positive and significant influence of QR on company profitability which is shown in this study is in line with the research results by Durrah et al. (2016) in food industry companies listed on the Jordanian stock exchange for the period of 2012-2014 and the research of Safdar et al. (2016) in the sugar industry in Pakistan in the period of 2007-2015. These studies confirmed that the high value of the company's QR ratio which indicated the high net working capital of the company had a positive and significant influence on the company's profitability as measured by ROA. 


\subsubsection{The Influence of Cash Ratio on Return on Assets (Hypothesis 4)}

The statistical tests conducted to determine the influence of cash ratio $(\mathrm{CaR})$ on return on assets (ROA) of this study show that the CaR has a non-significant influence on ROA (H4 is rejected). It means that the increase or decrease in the value of $\mathrm{CaR}$ has no influence on changes in the value of ROA.

The results of this study support that the CaR does not significantly affect ROA and it is in line with the research conducted by Rehman et al. (2015) and Shah et al. (2016) who found that CaR did not have a significant influence on ROA. Each company certainly had its own policy regarding the amount of cash that is needed to have in order to fulfill various operational needs and to pay the company's liabilities. This policy on the amount of cash was supported by other efforts to increase the profits such as increasing sales and cost-efficiency. Thus, the amount of the company's cash ratio did not significantly influence the profitability of the company.

\subsubsection{The Influence of the Cash Conversion Cycle on Return on Assets (Hypothesis 5)}

From the statistical tests that had been conducted, the results of this study supported that the cash conversion cycle (CCC) has no significant influence on ROA (H5 is rejected). The results of the data analysis supported that the CCC did not significantly influence ROA. It can be interpreted that the fluctuations in the length of the CCC of the company did not affect the increase or decrease in ROA. The results of this study are in line with the research results found by Bolek and Wili'nski (2012) and Samiloglu and Akgun (2016) who showed that the CCC change did not have a significant influence on the company's ability to generate returns on assets (ROA).

\subsubsection{The Influence of Good Corporate Governance Index (GCGI) on Return on Assets (Hypothesis 6)}

The sixth hypothesis statistical testing results in support for positive and significant influences of GCGI on ROA (H6 is accepted). The results of this study are in line with the research results by Cheung et al. (2007) which examined 168 large companies listed on the Hong Kong Exchange in 2002; Owusu and Weir (2016) which examined companies listed on the Ghana stock exchange in 2004-2009; and Chong et al. (2016) which examined REITs company as the objects in Singapore in 2008-2012. Research by Cheung et al. (2007); Chong et al. (2016); Owusu and Weir (2016) confirmed that there was a positive impact of GCG implementation on company profitability (ROA). The higher the quality of GCG, the higher the company's ability to produce a return on its investment.

\section{CONCLUSION}

The results provided a confirmation of the theories and results of previous studies that supported that there was no significant difference between the performance of multinational and domestic companies. Furthermore, this study proved that working capital management as measured by current ratio $(\mathrm{CR})$ and quick ratio $(\mathrm{QR})$ had a positive and significant influence on return on assets (ROA), but cash ratio (CR) and the cash conversion cycle did not have a significant influence on 
return on assets (ROA). This study also found that the Good Corporate Governance Index (GCGI) had a positive and significant influence on return on assets (ROA).

The managerial policy implications that can be taken in relation to the results of this study are that investors and company managers need to pay more attention to $\mathrm{CR}, \mathrm{QR}$, and GCGI. Investors can invest in companies that have high $\mathrm{CR}$ and QR and apply GCG consistently. Company managers need to be committed to implementing GCG on an ongoing basis to support better acquisition of protection. GCG implementation can be done by adopting the ASEAN CG Scorecard because the ASEAN CG Scorecard is used by the Indonesian Authorities (Financial Service Authority) to measure the GCG implementation which consists of eight principles such as: (1) Improve the Value of General Meeting of Shareholders (GMS); (2) Improve Communication Quality between a Public Company and its Shareholders or Investors; (3) Strengthen the Membership and Composition of the Board of Commissioners; (4) Improve Implementation Quality of the Board of Commissioners' Duties and Responsibilities; (5) Strengthen the Membership and Composition of the Board of Directors; (6) Improve Implementation Quality of the Board of Directors' Duties and Responsibilities; (7) Improve the Aspects of Corporate Governance through Participation of Stakeholders; (8) Improve the Implementation of Disclosure of Information.

This study had various limitations in the form of independent variables used to determine the variation of ROA which is still limited and assumed that the regression model used the common influence model. Based on the various limitations of this study, further research is suggested to expand the independent variables used and consider more recent analytical techniques.

\section{REFERENCES}

Albis, N., \& Álvarez, I. (2017). A comparative analysis of the innovation performance between foreign subsidiaries and owned domestic firms in Colombian manufacturing sector. Journal of Globalization, Competitiveness \& Governability, 11(2), 20-41.

Ameer, R. (2012). Impact of cash holdings and ownership concentration on firm valuation: Empirical evidence from Australia. Review of Accounting and Finance, 11(4), 448-467. https://doi.org/10.1108/14757701211279196

Aqil, M., Ahmed, R., Vveinhardt, J., \& Streimikiene, D. (2019). Factors Influencing the Profitability of Heavy Vehicle Industry: A Case of Pakistan. Montenegrin Journal of Economics, 15(1), 61-72. https://doi.org/10.14254/1800-5845/2019.15-1.5

Bagchi, B., \& Chakrabarti, J. (2014). Modeling liquidity management for Indian FMCG firms. International Journal of Commerce and Management, 24(4), 334-354. https://doi.org/10.1108/IJCoMA-10-2012-0065

Barbosa, N., \& Louri, H. (2005). Corporate Performance: Does Ownership Matter? A Comparison of Foreign- and Domestic-Owned Firms in Greece and Portugal. Review of Industrial Organization, 27(1), 73-102. https://doi.org/10/1007/s11151-005-4920-y

Bolek, M., \& Wili'nski, W. (2012). The influence of liquidity on profitability of Polish construction sector companies. e-Finanse: Financial Internet Quarterly, 8(1), 38-52.

Brigham, E. F., \& Houston, J. F. (2012). Fundamentals of Financial Management. Cengage Learning. 
Cheung, Y.-L., Connelly, J. T., Limpaphayom, P., \& Zhou, L. (2007). Do investors really value corporate governance? Evidence from the Hong Kong market. Journal of International Financial Management and Accounting, 18(2), 86-122. https://doi.org/10.1111/j.1467646X.2007.01009.x

Chong, W. L., Ting, K. H., \& Cheng, F. F. (2016). The impacts of corporate governance on the performance of reits in Singapore. Journal of Real Estate Literature, 24(2), 319-344. https://doi.org/10.5555/0927-7544.24.2.317

Durrah, O., Rahman, A. A. A., Jamil, S. A., \& Ghafeer, N. A. (2016). Exploring the Relationship between Liquidity Ratios and Indicators of Financial Performance: An Analytical Study of Food Industrial Companies Listed in Amman Bursa. International Journal of Economics and Financial Issues, 6(2), 435-441.

Ernayani, R., Oktiviana, S., \& Robiyanto, R. (2017). The Effect of Return on Investment, Cash Ratio, and Debt to Total Assets Towards Dividend Payout Ratio (A Study Towards Manufacturing Companies Listed in Indonesia Stock Exchange). Advanced Science Letters, 23(8), 7169-7199. https://doi.org/10.1166/as1.2017.9328

Gupta, P. P., Kennedy, D. B., \& Weaver, S. C. (2009). Corporate governance and firm value: Evidence from Canadian capital markets. Corporate Ownership \& Control, 6(2-3), 293307. https://doi.org/10.22495/cocv6i3c2p4

Handriani, E., \& Robiyanto, R. (2018a). Corporate Finance and Firm Value in The Indonesian Manufacturing Companies. International Research Journal of Business Studies, 11(2), 113-127. https://doi.org/10.21632/irjbs.11.2.113-127

Handriani, E., \& Robiyanto, R. (2018b). Investment Opportunity and Industrial Growth in Indonesia. International Journal of Business and Society, 19(2), 295-312.

Handriani, E., \& Robiyanto, R. (2019). Institutional ownership, independent board, board size, and firm performance: evidence from Indonesia. Contaduría y Administración, 64(3), e118. https://doi.org/10.22201/fca.24488410e.2018.1849

Hintošová, A. B., \& Kubíková, Z. (2016). The effect of the degree of foreign ownership on firms' performance. Review of Economic Perspectives, 16(1), 29-43. https://doi.org/10.1515/revecp-2016-0003

Hoang, T. V. (2015). Impact of Working Capital Management on Firm Profitability: The Case of Listed Manufacturing Firms on Ho Chi Minh Stock Exchange. Asian Economic and Financial Review, 5(5), 779-789.

Jensen, M. C., \& Meckling, W. H. (1976). Theory of the firm: Managerial behavior, agency costs and ownership structure. Journal of Financial Economics, 3(4), 305-360.

Keown, A. J., Scott, D. F., Martin, J. D., \& Petty, J. W. (2008). Dasar-Dasar Manajemen Keuangan. Jakarta: Salemba Empat.

Kinkyo, T., Inoue, T., \& Hamori, S. (2016). Financial Linkages, Remittances, and Resource Dependence in East Asia. Singapore: World Scientific.

Leng, A. C. A. (2004). The Impact of Corporate Governance Practices on Firms' Financial Performance: Evidence from Malaysian Companies. ASEAN Economic Bulletin, 21(3), 308-318.

Mai, M. U. (2017). Mediation of CSR and Profitability on the Influences of GCG Mechanism to the Firm Value. Jurnal Keuangan dan Perbankan, 21(2), 253-264.

Muharam, H., Mawardi, W., Handriani, E., Puryandani, S., \& Robiyanto, R. (2020). Corporate Governance Structure and Firm Performance in the Indonesian Capital Market. Quality Access to Success, 21(174), 22-27.

Munawir, S. (2007). Analisa Laporan Keuangan. Yogyakarta, Indonesia: Liberty. 
Orazalin, N., Mahmood, M., \& Lee, K. J. (2016). Corporate Governance, Financial Crises and Bank Performance: Lessons from Top Russian Banks. International Journal of Business and Society, 16(5),798-814.

Owusu, A., \& Weir, C. (2016). The governance-performance relationship: evidence from Ghana. Journal of Applied Accounting Research, 17(3), 285-310. https://doi.org/10.1108/JAAR06-2014-0057

Purnamawati, I. G. A., Yuniarta, G. A., \& Astria, P. R. (2017). Good Corporate Governance dan Pengaruhnya Terhadap Nilai Perusahaan Melalui Corporate Social Responsibility Disclosure. Jurnal Keuangan dan Perbankan, 21(2), 276-286.

Rehman, M. Z., Khan, M. N., \& Khokhar, I. (2015). Investigating Liquidity-Profitability Relationship: Evidence from Companies Listed in Saudi Stock Exchange (Tadawul). Journal of Applied Finance \& Banking, 5(3), 1-11.

Riyanto, B. (2011). Dasar-Dasar Pembelanjaan Perusahaan (4th ed.). Yogyakarta, Indonesia: BPFE UGM.

Robiyanto, R., Putra, A. R., \& Lako, A. (2019). The effect of corporate governance and intellectual capital toward financial performance and firm value of socially responsible firms. $\begin{array}{llll}\text { Contaduría } & \text { y } & \text { Administración, } & 66(1),\end{array}$ https://doi.org/10.22201/fca.24488410e.2021.2489

Ruangchoengchum, P. (2017). Performance Measurement that Affects SMEs Business Profits: Case Study of SMEs in Khon Kaen Province. ABAC Journal, 37(1), 26-42.

Safdar, M. Z., Awan, M. Z., Ahmed, Z., Qureshi, M. I., \& Hasnain, T. (2016). What Does Matter? Liquidity or Profitability: A Case of Sugar Industry in Pakistan. International Journal of Economics and Financial Issues, 6(S2), 144-152.

Samiloglu, F., \& Akgun, A. I. (2016). The Relationship between Working Capital Management and Profitability: Evidence from Turkey. Business and Economics Research Journal, 7(2), 1-14. https://doi.org/10.20409/berj.2016217492

Sayidah, N. (2007). Pengaruh kualitas corporate governance terhadap kinerja perusahaan publik. Jurnal Akuntansi dan Auditing Indonesia, 10(1), 1-9.

Shah, S., Tahir, S. H., Ullah, A., \& Iqbal, A. (2016). The Impact of Investment Diversification on Firm Performance. Abasyn Journal of Social Sciences, 20(S), 300-311. https://doi.org/10.24312/paradigms110105

Tahir, M., \& Anuar, M. B. A. (2015). The determinants of working capital management and firms performance of textile sector in Pakistan. Quality \& Quantity, 50(2), 605-618. https://doi.org/10.1007/s11135-015-0166-4

Talpová, S. Ž. (2016). Do they Compete Differently? Strategies of MNEs and Domestic Companies in the Environment of the Czech Republic. Trends Economics and Management, 10(27), 67-79. https://doi.org/10.13164/trends.2016.27.67

Thornblad, D. B., Zeitzmann, H. K., \& Carlson, K. D. (2018). Negative Denominators in Index Variables: The Vulnerability of Return on Equity, Debt to Equity, and Other Ratios. The Electronic Journal of Business Research Methods, 16(1), 1-10. 
Appendix 1: List of Research Sample

\begin{tabular}{|c|c|c|}
\hline No. & Code & Company Name \\
\hline 1. & ADES & PT Akasha Wira International Tbk. \\
\hline 2. & AKPI & PT Argha Karya Prima Industri Tbk. \\
\hline 3. & ALDO & PT Alkindo Naratama Tbk. \\
\hline 4. & AMFG & PT Asahimas Flat Glass Tbk. \\
\hline 5. & APLI & PT Asiaplast Industries Tbk. \\
\hline 6. & ARNA & PT Arwana Citramulia Tbk. \\
\hline 7. & AUTO & PT Astra Otoparts Tbk. \\
\hline 8. & BATA & PT Sepatu Bata Tbk. \\
\hline 9. & BRAM & PT Indo Korsa Tbk. \\
\hline 10. & BUDI & PT Budi Starch \& Sweetener Tbk. \\
\hline 11. & CEKA & PT Wilmar Cahaya Indonesia Tbk. \\
\hline 12. & CPIN & PT Charoen Pokphand Indonesia Tbk. \\
\hline 13. & DVLA & PT Darya-Varia Laboratoria Tbk. \\
\hline 14. & EKAD & PT Ekadharma International Tbk. \\
\hline 15. & GGRM & PT Gudang Garam Tbk. \\
\hline 16. & HMSP & PT HM Sampoerna Tbk. \\
\hline 17. & ICBP & PT Indofood CBP Sukses Makmur Tbk. \\
\hline 18. & IGAR & PT Champion Pasifik Indonesia Tbk. \\
\hline 19. & INAI & PT Indal Aluminium Industry Tbk. \\
\hline 20. & INDF & PT Indofood Sukses Makmur Tbk. \\
\hline 21. & INDR & PT Indo-Rama Synthetics Tbk. \\
\hline 22. & INDS & PT Indospring Tbk. \\
\hline 23. & INKP & PT Indah Kiat Pulp \& Paper Tbk. \\
\hline 24. & IPOL & PT Indopoly Swakarsa Industry Tbk. \\
\hline 25. & JECC & PT Jembo Cable Company Tbk. \\
\hline 26. & JPFA & PT Japfa Comfeed Indonesia Tbk. \\
\hline 27. & KAEF & PT Kimia Farma Tbk. \\
\hline 28. & KBLI & PT KMI Wire and Cable Tbk. \\
\hline 29. & KBLM & PT Kabelindo Murni Tbk. \\
\hline 30. & KDSI & PT Kedawung Setia Industrial Tbk. \\
\hline 31. & KLBF & PT Kalbe Farma Tbk. \\
\hline 32. & LION & PT Lion Metal Works Tbk. \\
\hline 33. & MERK & PT Merck Tbk. \\
\hline 34. & MLBI & PT Multi Bintang Indonesia Tbk. \\
\hline 35. & MYOR & PT Mayora Indah Tbk. \\
\hline 36. & NIPS & PT Nipress Tbk. \\
\hline 37. & PBRX & PT Pan Brothers Tbk. \\
\hline 38. & $\mathrm{PICO}$ & PT Pelangi Indah Canindo Tbk. \\
\hline 39. & PYFA & PT Pyridam Farma, Tbk. \\
\hline 40. & RICY & PT Ricky Putra Globalindo Tbk. \\
\hline 41. & ROTI & PT Nippon Indosari Corpindo Tbk. \\
\hline 42. & SCCO & PT Supreme Cable Manufacturing \& Commerce Tbk. \\
\hline 43. & SKBM & PT Sekar Bumi Tbk. \\
\hline 44. & SKLT & PT Sekar Laut Tbk. \\
\hline 45. & SMGR & PT Semen Gresik Tbk. \\
\hline 46. & SMSM & PT Selamat Sempurna Tbk. \\
\hline 47. & SRIL & PT Sri Rejeki Isman Tbk. \\
\hline 48. & SRSN & PT Indo Acidatama Tbk. \\
\hline 49. & STAR & PT Star Petrochem Tbk. \\
\hline 50. & TALF & PT Tunas Alfin Tbk. \\
\hline
\end{tabular}


51. TCID PT Mandom Indonesia Tbk.

52. TKIM PT Pabrik Kertas Tjiwi Kimia Tbk.

53. TOTO PT Surya Toto Indonesia Tbk.

54. TPIA PT Chandra Asri Petrochemical Tbk.

55. TRIS PT Trisula International Tbk.

56. TRST PT Trias Sentosa Tbk.

57. TSPC PT Tempo Scan Pasific Tbk.

58. ULTJ PT Ultrajaya Milk Industry \& Trading Co. Tbk.

59. UNIT PT Nusantara Inti Corpora Tbk.

60. UNVR PT Unilever Indonesia Tbk.

61. WIIM PT Wismilak Inti Makmur Tbk.

Source: Indonesian Capital Market Directory, processed. 